and are primarily concerned with solar astronomy and the study of cosmic rays. It is the first ESRO satellite to be launched; the launching of ESRO-1, which is devoted to an investigation of the polar ionosphere and aurorae, will probably be later this year. An earlier attempt at launching ESRO-2 took place almost a year ago-it was unsuccessful because exhaust gases burnt through the casing of the third stage engine of the Scout launcher. It must nevertheless be comforting to the designers of ESRO-2 that the satellite itself seemed to be working correctly during the abortive launch.

The orbit of ESRO-2, chosen to facilitate study of the Sun, will pass over the poles. The satellite will be launched into an orbital plane almost at right angles to the Earth-Sun line, and the plane of the orbit will rotate at the same rate as the apparent motion of the Sun around the Earth, so that the satellite will be in sunlight for most of the time. The perigee and apogee are $350 \mathrm{~km}$ and $1,100 \mathrm{~km}$, respectively, taking the satellite into the inner Van Allen belt.

\section{Testing, Testing}

For reasons of war and peace, the United States Atomic Energy Commission is stepping up the number of its tests of nuclear bombs. There will probably be twice as many tests in 1968 as there were last year, when 25 were announced and perhaps as many as 10 others took place. The one-megaton explosion that upset Mr Howard Hughes and Dr Barry Commoner among others last week is presumed to have been a step on the road to the thermonuclear warhead planned for the Sentinel anti-ballistic missile system.

The test, although it shook chandeliers in Las Vegas 100 miles away, did none of the dire things predicted; it did not start movement along the San Andreas fault in California, nor did it release radiation nor cause any serious damage to buildings. Nonetheless the explosion did seem in bad taste, coinciding with the opening of the General Assembly's debate on the non-proliferation treaty. But the AEC is making no bones about its plans to have more tests, and bigger ones. According to Dr Glen Seaborg, two new test sites are being developed, at a cost of about $\$ 40$ million. The intention clearly is to satisfy some of the AEC's crities who were more vociferous about the recent test than they have been for a long time. Yet the new sites-one at Hot Creek Valley in central Nevada, the other on Amchitka Island in the Aleutians-may not be beyond reproach. A calibration test conducted at Hot Springs broke some windows in northern California and Amchitka Island has been a government preserve for sea otters and seals.

Most of the new weapons tests are going to be in what the AEC describes coyly as "well above the intermediate range". Last month's explosion at the bottom of a 3,800 foot sealed shaft was the biggest ever held in the United States, above or below ground. Some of those who objected to it, in addition to Dr Commoner's Committee for Environmental Information in St Louis, were the Federation of American Scientists (with 2,200 members), the Women's Strike for Peace and a division of the United Auto and Aerospace Workers' Union.

But in the AEC's view the tests are safe. The geological structure of Nevada is such that most of the shock waves travel to the cast and the likelihood of radiation escaping is thought to be small. The AEC maintains that on the few occasions when there has been what it calls "venting", the radiation has not crossed the American frontiers. It has, on the other hand, inquired of the Soviet Union about three accidental discharges of radioactive debris which, after Russian tests, was carried beyond the borders of the Soviet Union. The Russians in turn have inquired about three of the Amcrican tests, but no formal protests have been mede on either side.

The AEC meanwhile is looking to its own future by practising techniques for mining metals and minerals by explosion; some day it might depend on commercial contracts for nuclear detonations to keep itself alive. The first such test to be done in partnership with private industry looks to have been a success. Project Gasbuggy, set off last December in the sandstone formations near Farmington, New Mexico, created an artificial chimney in the crushed rock. The hope of the El Paso Natural Gas Company, which shared the cost with the AEC, is that gas will have accumulated in the chimney to such an extent that its recovery will be relatively easy and cheap.

So far, samples of the gas which have been sent for analysis to the Lawrence Radiation Laboratory in Livermore, California, have shown little or no tritium or radioactive iodine. Any appreciable contamination of the gas could kill the outlook for its commercial production by such explosions. The final report on Gasbuggy will not be released for a year or more and actual measurements of the gas flow will not begin until the summer. But if things have gone as well as they seem to have done, Gasbuggy could be followed soon by five other commercial tests on the AEC's waiting list.

The culmination of the AEC's commercial ambitions would be the blasting of a new canal across the Isthmus of Panama. An Atlantic-Pacific Interoceanic Canal Study Commission is mulling over the diplomatic and technical obstacles to detonating thousands of nuclear explosions near a populated area. To provide some test information for this committee, an explosion confusingly labelled Project Buggy was performed in Nevada in January. Five nuclear explosives were buried in a row 135 feet deep and about 150 feet apart. The result was a trench 80 feet deep, 300 feet wide and 900 feet long - not quite enough for a new Panama Canal, but a beginning. About five per cent of the radioactiv. ity produced escaped from the crater; AEC officials found this acceptable. Whether Panamanians or the signatories to the test-ban treaty would agree is another matter, but it is not entirely out of the question that such a procedure would be agreed on.

\section{Ad Astra by Bus}

THe British aircraft industry is having its most cheerful year for a very long time. For once, it seems, there have been more orders than cancellations, and for the time being the merger (Government inspired) between Hawker-Siddeley and the British Aircraft Corporation is off. The two most important successes have been the selling of the Rolls-Royce RB 211 engine for the Lockheed airbus, and the order announced last week by BAC for guided missile systems for Libya. In the first two months of the year, the Society of British 